\title{
Settlement System of the Kazan County In the Middle of the XIX Century
}

\author{
Dina A. Mustafina ${ }^{1} \&$ Olga V. Luneva ${ }^{1}$ \\ ${ }^{1}$ Kazan (Volga Region) Federal University, Kazan, Russia \\ Correspondence: Dina A. Mustafina \& Olga V. Luneva, Kazan (Volga Region) Federal University, \\ Kremlyovskaya Street 18, Kazan 420008, Russia. E-mail: maktub29@yandex.ru
}

\author{
Received: April 14, 2015 Accepted: April 20, 2015 Online Published: April 27, 2015 \\ doi:10.5539/jsd.v8n4p218 URL: http://dx.doi.org/10.5539/jsd.v8n4p218
}

\begin{abstract}
The urgency of the problem under investigation is caused by the fact that the system of the settlement is the basis and the indicator showing the change in the spatial characteristics, as well as a measure and the reflector of the nature of social and economic processes in a particular area, in this case - Kazan County. The purpose of the article is to familiarize with the first attempts to implement spatial and statistical analysis of data on rural settlement in the middle of the XIX century using the methods of modern computer technology. Leading techniques to the study of this problem are the methods of spatial and spatial-statistical analysis of the data. To visualize the settlement structure of the Kazan district an electronic cartographic base was used, established on the basis of the map of 1910. The localization of the settlements accounted by the Ministry of Internal Affairs in 1859 , and a spatial analysis of the current settlement system revealed the areas of the greatest concentration of the settlements, relatively uniform distribution of settlements on the existing three county units of the County and uneven distribution of different their types, socio-ethnic and religious heterogeneity of the population, the direction of the main vector of economic and economic development, the beginnings of the industrial production in the county. Study materials are the most time-consuming and defining step in the creation of the historical geographic information system (GIS).
\end{abstract}

Keywords: historical GIS, settlement structure, settlement, localization of villages, settlement system, Kazan County

\section{Introduction}

\subsection{The Urgency of the Problem}

The study of the society, socio-economic processes, the historical experience of the interaction of various historical social structures - the interaction of cities and villages, multi-religious and multi-ethnic population make it necessary to study the spatial organization of the existing settlements in the Middle Volga region, which has become largely the result of colonization and economic development of the region. Settlement system reflects the spatial and demographic changes that took place as a result of new capitalist relations penetration into the village, reveals the changing forms of organization of the network of settlements, their status in the existing system, identify likely changes in the existing residential structure and prospects of development of human settlements and social strata. Reconstruction of historical settlement system may be helpful in developing reasoned proposals for the organization of social and economic functioning and social policy in the society at the micro-level of a particular area and at the present stage of development.

\subsection{The Need of the Problem}

The planned establishment of geographic information system (GIS) spatial organization of settlements in the Middle Volga region in the second half of the XVI-XIX centuries. involves compiling electronic cartographic base, database and GIS applications. Working on the cartographic base involves geographic connection of settlements with the frequency with which they have been recorded and described. Each of the sections of information on settlements reflects the uniqueness of the settlement structure and helps to reveal her identity, and together these sections help define the dynamics and trends in its development. Consequently, the reference to the issue of the settlement system in the Kazan district in the middle of the XIX century seems to be a necessary link in the realization of the aim. 


\subsection{Features of the Kazan County}

The Kazan County, associated with the entry of the former Khanate of Kazan in the Russian state in the second half of the XVI century, was a central part of the political body which lost its independence. It was decisive and significant for the study of the tolerant interaction of interfaith and multiethnic population.

\subsection{The Purpose and Objectives of the Study}

The aim is the implementation of spatial and statistical analysis of data on rural settlement in the middle of the XIX using methods of geo-information technologies. The research work was aimed at addressing three interrelated tasks involving establishment of historical GIS (Holdsworth, 2003), visualizing the spatial organization of settlements, population and population density of the Kazan district and allowing not only to store and process information of attributive nature, but also to replenish it subsequently (Schlichting 2008; Knowles, 2008; Southall, 2009). Since the cards are the main method of storage and presentation of spatial information for historical research, the first objective of the study was to create electronic cartographic basis for the XIX century. The second objective was the localization of settlements accounted by the Ministry of the Interior in 1859 (Artemyev, 1866). The third objective was a spatial analysis of social and ethnic components of rural settlements in the period of interest to us.

\section{Materials and Methods}

\subsection{Cartographic Material and Methods of Working with It}

We have studied the experience of foreign and domestic counterparts on the use of GIS in historical research (Piotuh, 2004; Vladimirov, 2005; Piotuh 2005; Healey, Delve, 2007; Zhikhareva, 2011; Schwartz et al., 2011; Coughlin et al., 2012 ; Konchakov, Baranov, 2012; Gregory, Cooper, 2013; Knowles, 2013; Historical Information Science, 2013). As a software to create GIS package we used ArcGIS 10.2 (ESRI, USA) and EASY TRACE PRO 8.7 (EASY TRACE GROUP, Russia), and vector base map representing modern topographic base 200000 scale the coordinate system Pulkovo 1942 and cylindrical conformal projection Gauss-Kruger. For a basis of historical topographic base we took "Special map of European Russia" in 1875 (scale: 1 inch 10 miles) published by Military Topographical Department of the General Staff, edited by well-known Russian cartographer, surveyor general of infantry, IA Strelbitsky. This map, consisting of 178 pages, was the most detailed atlas of the European part of the Russian Empire. Map scale in the atlas was 10 verst to the inch $(1 \mathrm{~cm}$ $4,2 \mathrm{~km}$ ). The territory of Kazan outskirts or Kama region and the main area of the West Zakamye of modern Tatarstan occupy 109 sheet (Strelbitsky, 1875). Borders of provinces and counties are carefully marked on the map, almost all the rivers, lakes, roads are drawn, large and small towns and the surfaces covered by forest are indicated. This fact allowed registering the map in the geographical space with conversion of coordinates to the current GMT with further geo-correction of binding on the drainage system. Binding error did not exceed 100-150 m. Map vectoring was carried out in the program EASY TRACE PRO 8.7 as separate layers: 1) the point of the grid, grid; 2) large settlements, smaller settlements; 3) the network of rivers, water bodies; 4) borders of districts, boundaries of the provinces; 5) road network and forests. All these layers were imported into ArcGIS. Then, three more maps were added to the GIS project. First of all, this is a color 30 versts (miles) map of the Kazan province in the middle of the XIX made by the court counselor P.Zhiganov (ABDULLIN et al., 2013) and is characterized by the fact that it outlines the boundaries of the villages and notes the places of apartments in villages. Then four color map "Statistical map ..." in the National Archives of the Republic of Tatarstan, which carries information on the hydrographic system, towns, highways, including rural roads, as well as agricultural land and forests (ABDULLIN et al., 2013 ). Finally, there was a "Map of the Kazan County ..." compiled in 1910 by the Statistical Office of the Evaluation of the Kazan provincial zemstvo. (National Archives of the Republic of Tatarstan). Of all the above mentioned maps the last one is the most detailed and informative. In addition to detailed orography and hydrography, forest and all inconvenient for agricultural use areas, counties borders and townships were recorded on it, main lines of county roads, railway tracks, roads, post roads with post stations and branches were indicated, the sites of township boards were marked. When specifying the areas of forests, state-owned and specific ownership were differentiated, forests belonging to the city of Kazan were noted, and within forest areas - even to specific people. Spatial organization of settlements is carefully reflected on the map. 4 groups of villages depending on the number of inhabitants are shown in this system. There were more than 1000 people in the largest settlements and further downward from 500 to 1000 , from 100 to 500 to 100 people. After careful study and analysis of the available maps, the map published in 1910 was adopted for the base. (National Archives of the Republic of Tatarstan). As you know, maps allow a one-time review of unlimited territory settlement, reflect the spatial structure and contain a variety of quantitative and qualitative characteristics of mapped objects. The possibility of an e-map is even wider. Allocation for a given thematic 
principal of different map layers is indispensable for identifying patterns and characteristics of the placement of the peasant population and the ranks along ethnic lines, to identify key areas of their resettlement, to identify relationships of natural and geographical features of the region with demographic factors (population density, etc.).

\subsection{Characteristics and Creation of a Historical Database}

The database on the rural population has been established on the basis of the "List of settlements" of the Kazan province (Artemyev, 1866). The information collected can be attributed to two types (descriptive and statistical), consisting of a group of elements or fields. The first, descriptive field group includes the name of the county, the number of the camp, to which the village belongs and which specifies the location of the village. The second group of fields - is the serial number, type of settlement (a village, a small village, pochinok, zaymische, etc.), the name of the village (including all former names) and the nature of ownership of the village (possessory, specific, state-owned). The third group of fields is a topographic position of the village. It fixes geographical landmarks: hydro binding and an indication of the distance from St. Petersburg and Moscow for the provincial capital, from the provincial city for cities, including the centers of "internal" counties, from the county town and camp apartments for other villages. The fourth group of fields contains the statistical data: the number of houses (in urban areas), yards (in villages), population, and number of houses of worship, schools, the number of postal stations, and the number of factories. In the fifth group of fields the dislocation of market places, indicating the days of the week on which they were organized is marked. In the last field the specifying information, extending the idea of a particular mapped object was given.

\subsection{Localization Features of County Settlements}

This information supplied or "plug-in" database was compared with the database of these maps, which enabled more accurate geographical reference of recorded settlements in the list. In the identification of settlements the localization of the administrative-territorial units of a county, stans, or county units, was made. The location of a particular item was specified according to the topographic information and guidance about the remoteness of settlements from the district center or a point where there was a county unit apartment. The fact that recently formed settlements, marked on the historical maps as pochinki, had no names and it caused difficulties in defining their localization. In such cases, the odnoverstny General subdivision plan was used As a result of this labor-intensive operation it was possible to locate all 386 settlements recorded in the list and also to create a new vector layer showing more precise county units' boundaries for the electronic map of the XIX century.

\section{Results}

\subsection{The Overall Picture of Land Tenure and Land Use}

Kazan district on the eve of the abolition of serfdom was one of the developed areas of the Russian state with the general population living in rural areas. The majority of settlements were villages that arose long before accounting in $50 \mathrm{~s}$. More than three quarters $(75.5 \%)$ of settlements were administrated by the Treasury, nearly $18 \%$ were possessory and $6.2 \%$ belonged to the specific department. Types of settlements indicate, first of all, the continuing diversity of land tenure and land use forms. In the county, there are state-owned (former state or tributaries), private (former estate and patrimonial) and specific (former palace) lands. Typically, the vast majority of settlements in the first county unit were possessory, and in the rest of the county there were mainly state-owned villages. The location of residential places shows that the population preferred to live near natural water sources, mainly on the banks of rivers $(51.6 \%)$, near the keys, streams and springs $(28.12 \%)$, near lakes $(7.03 \%)$. The location of the villages near swamps, ravines and away from rivers and streams can be explained by different factors: the later choice of residence, the desire to take areas that were not conducted by the authorities, the implementation of economic development of new territories by people from other regions.

\subsection{Ethnosocial and Religious Characteristics of the Population}

The population of the Kazan County was not uniform: they differed in social, ethnic and religious features. Socially, it is possible to distinguish state-owned (mainly former tributaries), landlords (owners') and specific peasants. The peculiarity of the socio-economic development of the county was defined by the presence of fertile arable land, meadows, forests and the natural development of the river system that predetermined the occupation of the peasants. The main occupation of the population was grain production and animal husbandry. The economy remained generally natural, but there were bazaars at those times and, therefore, the production to the market also took place. In total, the county trade on the open area was carried out in 9 places, in $2.3 \%$ of the total number of villages from all settlements. Trading operations in each place took place on a strictly certain days of the week. It is curious that on Fridays markets were not organized, that in 6 out of 9 cases this form of trade took 
place in the Muslim villages, in the remaining 3 cases - in villages with a newly christened population (among the latter was a possessory small village). It seems that traditionally bazaars were located in historical exchange places. In the analyzed data there are facts pointing to property differentiation of the county population and the existence of some really wealthy people. There were eight industrial plants in the county: three plants - leather, potash and distillery, and five factories - four kitaechnye plants and one kumachnaya plant. Of course, their share in the whole county economy was negligible: less than $2 \%$. The plants were located in the owners' newly christened villages and factories were in state Muslim villages. If plants used exclusively local raw materials, the fabric production required imported raw material - cotton. It was imported from Central Asia by Tatar merchants to the Volga region. Almost all of them lived in rural areas and some of them managed to establish a factory to produce cotton fabric (cloth) - Gudulu (blue) and calico (red). It is known that Russian products were not inferior in quality to the imported cotton material, and the price was lower. In 1825, Russia began to export significant quantities of the fabric to China (Zaitsev, 1858). The County had a complex composition of the population, different in social and ethnic and religious characteristics. Ethnically the county population was represented by the Tatars, Mari, Udmurt, Chuvash, Mordovians and Russian. From the confessional point of view we can speak only about Russian uniformity, who was Orthodox Christians. The overwhelming majority of Tatars professed Islam, but a certain part of them were Christians. Mari, Udmurt and Chuvash mostly remained pagans, but there were some who professed Islam and Orthodoxy. A significant part of Mordovians were Christians, however, there were followers and supporters of polytheism among them. About in a third of the villages $(32.3 \%)$ there were mosques and in $13 \%$ of settlements - churches, including 3 monasteries and 3 chapels. There were no religious buildings in more than half of the county settlements. This, to some extent indicates the presence of pagans in the county, at the same time allows us to talk about active economic development of the region and internal migration. Indeed, in most cases, migrants were unable to immediately acquire the appropriate places or buildings for accomplishing the service. Considering ethno-religious aspect, the Orthodox population prevailed in the first county unit, in the second - the Muslim population, in the third - the population was mixed. Hence it appears that the first county unit, which covered the territory to the south and south-east of Kazan, became "closer" for the government in terms of religious affiliation of the population than the second and third county units. However, this area was less populated than others. This situation is the result of combined factors. Among the most significant of which is the need for further development of economic and colonization of the southern and south-eastern areas adjacent to the Kazan district in the past. The government periodically resettled serving people and the feudal-dependent population of the Kazan County to new regions - in Astrakhan, Azov, Voronezh, etc., to still being built fortified settlements - cities and palace villages, settlements on the defense line. The peasants themselves, tributaries and free people moved about the territory of the region and went to new lands without seeking permission from the authorities. It should be taken into account that the border areas were exposed to hostile invasion of steppe peoples, accompanied by destruction and capture of the population.

\subsection{Population Resettlement in the Kazan County}

Spatial statistical analysis showed that in the Kazan county different types of villages were distributed unevenly through the county units. The most densely populated areas were concentrated in the third and second county units along Arsky tract, in the northwest of the county and to the west of the city of Kazan, near Galitsky tract. The population density was associated with the location of the village, depended on the nature of the transport line (rivers, paths and country roads). The location and concentration of villages with Orthodox population reflect the trajectory and vector of the colonization process that was directed from the north and the northwest to the south and southeast. Since residential settlements of the Orthodox population were near rivers, we can make a conclusion that the Russian population from other regions reached the Kazan County moving along the rivers. The population, settled on the river banks, was able to control the movements along the waterways and ultimately got a significant advantage over the inhabitants of the settlements far from the river. Due to the favorable geographical position they were engaged in a variety of crafts, they were drawn into the trade and monetary relations. The concentration of Muslim villages in the north-eastern part of the county showed the interest of the tsarist government in the further colonization of the land, located in the southern and south-eastern directions. However, this fact points to the obvious attraction of the places for migrants where they settled, as well as different causes of forced resettlement and the departure of the former population of this area. The northwest area with the concentration of the Muslim and pagan residential settlements was not considered to be the area of priority development. Therefore, these lands remained outside the main stream of colonization.

\subsection{Spatial-social Organization of the County}

During this period, the Kazan County consisted of three county units, which broke into townships. Typically, the administrative and police district of the second quarter of XIX century., the so called county unit, geographically 
coincided with the county unit - the administrative and territorial unit, established in the Kazan district at the end of the XVI century and formed the part of the traditional division of the region into "daruga" (Mustafina, Yermolaev, 2001). Whereas, county, world, rural areas and counties in the region were formed without any regard to the administrative and police division of the districts. Out of 386 settlements one settlement - the city of Kazan had the status of the county town, the second - Arsk - the status of the center of the internal County. This means that up to 60s. XIX century separate counties were still formed. The remaining 384 settlements were rural, 126 were resettled to the first county unit, 135 - to the second and 123 villages - to the third. By the time of occurrence of the settlement they were divided into two types: those appeared prior to the previous account, and founded after this account. The predominant type of settlements was a village; its share in the total number of settlements was more than three-quarters $-75.1 \%$. The share of small villages stood at $10.9 \%$, selets $-7.3 \%$, pochinok $-4.9 \%$ of the total number of villages. Two settlements, monastic settlement (desert) and the farm together accounted for only $1.3 \%$, the share of cities accounted for only $0.5 \%$. The first county unit included areas located to the south and south-east of Kazan. The location of the police officer of the first county union was a former village Permyaki, which had two other names - Ugryumovka and Bogorodskoe. It was in charge of six townships. A characteristic feature of the spatial and social organization of this part of the county was the predominance of the Orthodox population. The vast majority of villages and small villages were located here and the definition of the type of the settlement indicated the presence of churches and chapels in them. The ratio of the villages was roughly equal. From the west the first county unit adjoined the third county unit, and to the north-eastern border of the first and third county units adjoined the second county unit. The typical type of settlements was a village and there were both Muslim and Orthodox population settlements. With the latter located mainly along the border between the first and the third county units, and in the southern part of the third county unit, i.e to the west of Kazan. The second county unit was different from other administrative-territorial County units; it had pochinki and their presence accounted for $14 \%$ of the total number of villages of the county unit. Settlements of the Orthodox population were very rare in that county unit. The apartment of the bailiff of the second county unit was located near Kazan in a provincial town Arsk. He was in charge of seven townships. The bailiff of the third county unit was in Sviyazhsk, the main city of the same name independent county. He was in charge of the seven townships. The first county unit was inferior to the other two, both in the number of households and the number of residents. In general, the villages were relatively big in the number of households: in the overwhelming majority $(60 \%)$ of the settlements the number of households did not exceed 50 yards. Altogether, the Kazan county consisted of 18,721 yard, they were distributed unevenly through the county units; 5.010 households $(26.8 \%)$ were in the first county unit, 6.468 (34.6\%) households were in the second and 7.223 $(38,6 \%)$ in the third. In one quarter of the settlements this figure ranged from 51 to 100 yards. In $13 \%$ of settlements the number of households reached from 101 to 200, more than 200 households were reported only in $1 \%$ of the villages. In the first county unit there were 17,545 men and 19,359 women. While the number of men in the second county unit was 27,797 and in the third $-27,566$ people. There were 27.880 women in the first county unit and 29,580 in the second. It can It can be noticed that the population of the first county unit (24.6\%) significantly lost to the second (37\%) and to the third (38.4\%). Attention should be drawn to the fact that the number of female population was higher than the number of men on 1.814 people in the first county unit, on 231 people in the second and on 1,700 people in the third. Male to female ratio was similar among the Muslims, and the female population prevailed over the male among the Orthodox.

\section{Discussions}

Until now the territorial distribution of peoples in Middle Volga region research remains insufficient. The fact is that there is an opinion in scientific literature that there is no ethnodemographic materials, including the information about the resettlement of ethnic groups in the XIX, except the 1897 census. Meanwhile, the data about the features of the peoples' settlements of the Middle Volga region are given in the writings of PI Koppen (Keppen, 1861), overviews and General Staff officers descriptions, list of settlements of the Central Statistical Committee of the Ministry of Foreign Affairs and others. VM Kabuzan paid particular attention to the information when studying historical dynamics of the population and areas of resettlement of peoples of Russia as a whole (Kabuzan, 1963; Kabuzan, 1971). A special study of the spatial organization of settlements in the Middle Volga and in some of it areas was not carried out. In works devoted to ethnic and ethno-geographical processes the question we are interested in is considered in materials related mainly to the early period until the XVI century or to a later time - the end of the XIX century. Attempts to use GIS technology in the analysis of source materials of the region we are interested in was not taken. The study of settlement systems in the Kazan county is motivated by the desire to consider the socio-economic, ethnic and demographic processes and issues of multinational cooperation in the area of active ethnic contacts in the context of the economic development of the region. 


\section{Conclusion}

Spatial statistical analysis showed that in the middle of the XIX century the main type of settlements in the Kazan county was villages and small villages - more than $85 \%$ of the total. Many of the settlements had two or three names that points out that the settlements under study were old and that their inhabitants might have changed very quickly. The highest concentration of residential settlements was observed to the west and northwest of Kazan, along postal Arsky tract and near the shopping Galitsky tract which ran through the territory of the second and third county units. The active migration of the population to the north-east of the county town was noticed and it can be proved by the existence of pochinoks, the settlements that appeared after the previous accounting. During the period from 1859 to 1910 on the created thematic maps the population growth and increased population density in the northwest of the second and third county units and along Arsky tract can be clearly observed. Consequently, the most favorable domestic political and socio-economic conditions for economic activities developed in this part of the county. Depending on the type of ownership settlements were divided into three groups: state-owned, the owners' and specific, i.e, there were three forms of feudal land ownership in the county and as a result there were different social categories of the rural population. Social stratification was aggravated by multi-ethnicity and religious heterogeneity of the population. In the process of integration of the Middle Volga region in the Russian state the dual protective ring, ensuring the safety of the city, was built around the county center. The first ring consisted of the settlements with the Orthodox population, and the second of settlements mainly with the Muslim population, certified as a state-owned settlements. The location of settlements in the county also leads to the conclusion that the settlements of the Muslim population were outside the mainstream of the colonization movement which was aimed at the south and south-east of the border of the county. The trajectory of this "flow" can be traced to the location and concentration of residential areas with Orthodox population. In short, the settlement structure of the Kazan county, ethnosocial and religious composition of the population reflect the results of the socio-political and economic-economic policy of the tsarist government. The work on digitization (vectorization)of the maps, location of settlements and the creation of a database of the County rural population and making GIS applications do not mean the end of the study on the GIS development. We hope it will continue and will be connected with the determination of the dynamics of economic and demographic characteristics of the settlements, identification of different patterns in the formation of new settlements. Implementation of the plans will require analysis of new documentary source materials.

\section{Recommendations}

The research material can be used in determining the stages of settlement structure development in the Middle Volga in the second half of the XVI-XIX, when creating a regional GIS in the historical geography of settlement structures, in the development of theoretical, methodological and technological information, as the basis of history of the Middle Volga, in the application of the theory of information processes and systems, as well as in the educational process, in courses of lectures on historical geography, historical demography, national history, history of the Tatar people.

\section{Acknowledgments}

The work is performed according to the Russian Government Program of Competitive Growth of Kazan Federal University

\section{References}

Abdullin, H. M., Mustafina, D. A., \& Sitdikov, A. G. (2013). Formation of a database of historical sources the second half of XVI the first half of the XVII century for the geographic information system of the Kazan region. Scientific notes of the Kazan University, 155(3), 66-78.

Artemyev, A. I. (1866). List of localities according to the 1859 (Vol. XIV, pp. 5-22). St. Petersburg.

Gregory, I., \& Cooper, D. (2013). The interdisciplinary mapping of the past: Geographical technologies, history and texts. Journal of Victorian Culture, 18, 265-272. http://dx.doi.org/10.1080/13555502.2013.797686

Healey, R. G., \& Delve, J. (2007). Integrating GIS and data warehousing in a web environment: A case study of the US 1880 census. International Journal of Geographical Information Science, 21, 603-624. http://dx.doi.org/10.1080/13658810601135742

Historical Information Science. Information Technology and Quantitative Methods in Historical Research and Education. (2013). Retrieved March 20, 2014, from http://aik-sng.ru/

Holdsworth, D. W. (2003). Historical geography: New ways of imaging and seeing the past. Progress in Human Geography, 27, 486-493. http://dx.doi.org/10.1191/0309132503ph440pr 
Kabuzan, V. M. (1963). The population of Russia in XVIII - first half of XIX century (based on audits). Moscow.

Kabuzan, V. M. (1971). Changes in the distribution of the population of Russia in XVIII - first half of XIX century. Moscow.

Keppen, P. I. (1861). Chronological index of materials for the history of foreigners in European Russia. St. Petersburg.

Knowles, A. K. (2008). GIS and history. In A. K. Knowles (Ed.), Placing History: How maps, spatial data, and GIS are changing historical scholarship (pp. 1-26). Anne Kelly Knowles. Redlands, California: ESRI Press.

Knowles, A. K. (2013). The contested nature of historical GIS. International Journal of Geographical Information Science, 28, 206-211. http://dx.doi.org/10.1080/13658816.2013.850696

Konchakov, R. B., \& Baranova E. V. (2012). Geographic information systems in studies of social history: current trends. InterCarto-InterGIS-18: Sustainable Development of Territories: GIS theory and practical experience. Proceedings of the international conference, Smolensk (pp. 303-307). Smolensk.

Kulin, D. V., Lopandya A. V., Nemtinov V. A., \& Podolsky V. E. (2012). Experience in the use of GIS technology in the educational process and scientific research Tambov State Technical University. Problems of modern science and practice, 39, 179-183.

Mustafina, D. A., \& Yermolaev, I. P. (2001). Cadastres Seeds Volyn as a historical source. In D. A. Mustafina, \& I. P. Yermolaev (Eds), Cadastres Kazan County's 1647-1656 (pp. 3-21). Moscow.

National Archives of the Republic of Tatarstan. Fund 324. Inventory 728. Case 1086a.

Piotuh, N. V. (2004). Cartographic method in historical research. In V. P. Vampilova (Ed.), Historical Geography: Theory and Practice (pp. 30-38). St. Petersburg.

Piotuh, N. V. (2005). Rural settlement in Russia in the second half of the XVIII century: comparative regional analysis. In L. I. Borodkin, \& V. N. Vladimirov (Eds.), Range of ideas: algorithms and technologies of historical information. Proceedings of the IX Conference of the Association "History and Computer" (pp. 282-311). Retrieved from http://www.aik-sng.ru/text/krug/2005/282-311.pdf

Schlichting, K. (2008). Historical GIS: New ways of doing history. Historical Methods, 41, 191-196. http://dx.doi.org/10.3200/HTMS.41.4.191-196

Schwartz, R. M., Gregory, I. N., \& Thevinin, T. (2011). Spatial History: Railways, Uneven Development, and Population Change in France and Great Britain, 1850-1914. Journal of Interdisciplinary History, 42(1), 53-88. http://dx.doi.org/10.1162/JINH_a_00205

Southall, H. (2009). Anne Kelly Knowles (ed.). Placing history: how maps, spatial data, and GIS are changing historical scholarship (Redland: ESRI Press, 2008). International Journal of Humanities and Arts Computing, 3(1-2), 203-207.

Strelbitsky, I. A. (Eds.). (1875). A special map of European Russia with the adjacent part of Western Europe and Asia Minor (pp. 109). St. Petersburg: Military-topograficheskey department Military Topographic Directorate of the General Staff, Russia.

Vladimirov, V. N. (2005). Historical Geoinformatics: geographic information systems in historical research. Barnaul.

Zaitsev, K. (1858). Essay on the development and production of this provision kitaechnogo. Kazan.

Zhikhareva, O. I. (2011). Some aspects of the geography of settlement Yaroslavl Upper. Yaroslavl Pedagogical Gazette, 2(3), 143-147.

\section{Copyrights}

Copyright for this article is retained by the author(s), with first publication rights granted to the journal.

This is an open-access article distributed under the terms and conditions of the Creative Commons Attribution license (http://creativecommons.org/licenses/by/3.0/). 